\title{
Short-term fluctuations in bivalve larvae compared with some environmental factors in a coastal lagoon (South Portugal)*
}

\author{
LUÍS M. Z. CHÍCHARO and M. ALEXANDRA CHÍCHARO \\ Universidade do Algarve, UCTRA- CCMAR, Campus de Gambelas, 8000810 Faro, Portugal. E-mail:lchichar@ualg.pt
}

\begin{abstract}
SUMMARY: In this study, short-term fluctuations in bivalve larvae were compared with some triggering factors for a period of sixteen months. Data on the abundance of planktonic larvae, collected two to three times a week were related to water temperature, salinity, wind velocity, tidal amplitude and chlorophyll a. Higher densities of planktonic bivalve larvae were caught between May and August, but intense fluctuations in abundance were observed. Planktonic bivalve larvae of eighteen taxa were identified. Larvae of Mytilus galloprovincialis, Cerastoderma edule, Ruditapes decussatus and Venerupis spp. were the most abundant. The seasonal fluctuations of bivalve abundance seem to be controlled by temperature, the major factor in the timing of the reproduction of bivalves. Nevertheless, advection may be also a key factor during the planktonic life of bivalve species in coastal systems, such as the Ria Formosa.
\end{abstract}

Key words: bivalve larvae, supply-side ecology, coastal lagoon.

\section{INTRODUCTION}

The Ria Formosa has a long tradition of bivalve harvesting, especially Ruditapes decussatus and Cerastoderma edule, contributing $90 \%$ of Portuguese production. The high productivity of shallow coastal lagoons, such as Ria Formosa, is the result of the contact of the water column and the sediment with good light conditions (Sprung, 1994a).

Despite their ecological importance, bivalve larvae have not received much attention in this area or in other locations. Seasonal and annual observations of the occurrence and abundance of bivalve larvae in the plankton have been made by a few authors, such

\footnotetext{
*Received May 19, 2000. Accepted August 29, 2000.
}

as Lebour (1938), Sullivan (1948), Rees (1954), Hrs-Brenko (1971), Alcaraz and Domínguez (1985), Mann (1988), Kalyanasundaram (1987), Leal (1989) and Chícharo (1993, 1996). General knowledge of bivalve larvae ecology will allow a better understanding of the environmental processes that determine the magnitude of bivalve recruitment. The dynamics of larvae from planktonic populations have important implications for the life histories of marine benthic invertebrates (Vance, 1973a,b; Strathmann, 1985; Hines, 1986). Thorson (1950, 1966) highlighted the impact of larval mortality in the recruitment of benthic populations. In fact, rates of growth and natural mortality can vary among populations of larvae (Chícharo and Chícharo, 2000), and the availability of settling larvae may influence patterns of recruitment. From the perspec- 
tive of supply-side ecology, the importance of larval abundance for the recruitment of benthic marine invertebrates is a determining factor in structuring benthic marine communities (Gaines and Roughgarden, 1985; Minchinton and Scheibling, 1991; Miron et al., 1995). However, this approach has been widely overlooked by benthic and planktonic ecologists. Most of these investigations monitored larval patterns with a coarse temporal resolution (often months, according to Grassle and Grassle, 1974 and Maurer et al., 1979), and therefore failed to identify periods when structuring phenomena occurred (Roegner and Mann, 1995). Difficulties in the identification of bivalve larvae also hamper the calculation of overall larval abundance in the plankton. Only a very intense sampling regime, involving laborious and time consuming laboratory work with short-term intervals and simultaneous temporal sampling of planktonic larvae allows data series to be obtained in realistic time intervals.

Several environmental factors, such as temperature and salinity (Calabrese, 1969; Kingston, 1974; Hrs-Brenko, 1978), food concentration (Pechenik et al., 1990), physical mechanisms (Belgrano et al., 1995, Morgan, 1994, Richards et al., 1995), predation (Young \& Chia, 1987) or settlement (CáceresMartinez and Figueras, 1998 a,b) may affect bivalve larval availability. Whereas in laboratory experiments some of these factors have been studied, their influence in natural habitats is unknown.

The principal aim of this study was to analyse short-term fluctuations in bivalve larvae abundance in a coastal lagoon (Ria Formosa, South-Portugal), for a period of sixteen months, and compare them with some environmental factors. Water temperature, wind speed, tidal amplitude and a food availability indicator (chlorophyll a) were analysed in order to determine the triggering factors of bivalve larvae abundance fluctuations.

\section{MATERIAL AND METHODS}

\section{Study site}

Bivalve larvae and post-larvae were collected at the Ria Formosa lagoon, in the south of Portugal. This is a tidal lagoon, consisting of a system of salt marshes, creeks and tidal flats extending for about $55 \mathrm{~km}$ in length and up to $6 \mathrm{~km}$ in width (Fig. 1). Connection with the Atlantic Ocean is established through two major openings (Faro-Olhão bar and

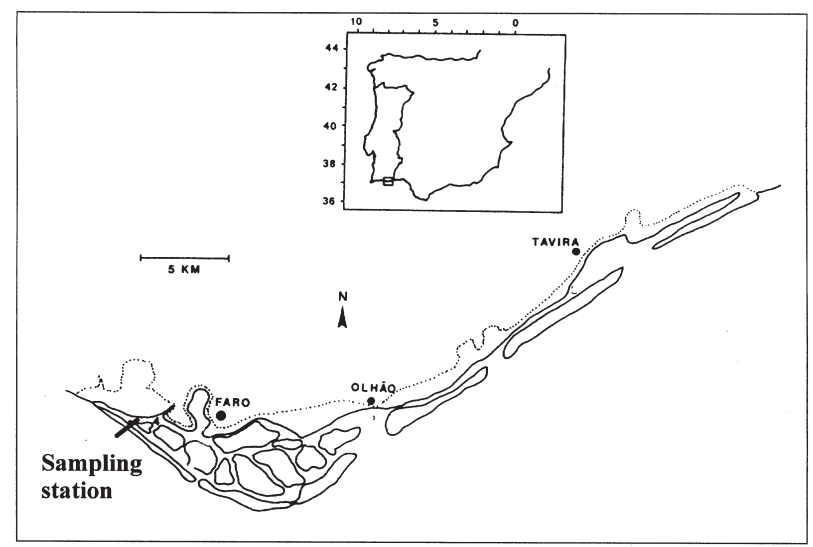

FIG. 1. - Map of the Ria Formosa (South of Portugal) showing the sampling station.

Culatra bar). The exchange of water between the Ria and the adjacent ocean is about $50-75 \%$ in each tidal cycle (Águas, 1986). Water temperature varies from about $12-13^{\circ} \mathrm{C}$ in winter to $27-28^{\circ} \mathrm{C}$ in summer. However, in summer and during ebb tides, water temperature can rise to $\approx 30^{\circ} \mathrm{C}$ in more interior and shallower regions of the Ria. Only one river, the Rio Gilão, flows into the lagoon. This is an unimportant water source with little impact on variation in salinity, which ranges between 25.5 and 36.9 PSU (Falcão et al., 1985).

\section{Environmental parameters}

These parameters were measured two to three times per week during the spring and summer months in the larval sampling station (Fig. 1). This is when the more intense bivalve spawning occurs in the area (Chícharo, 1996). During the rest of the year, measurements were made once a week. Water temperature and salinity were measured with a Kent Eil 5005 MC5 probe. Wind velocity and direction data were obtained weekly from the Meteorological Service of Faro Airport, which is directly adjacent to the study site. Chlorophyll a was determined spectrophotometrically and measurements were corrected for phaeopigments (Lorenzen and Jeffrey, 1980).

\section{Sampling and laboratory processing}

Plankton samples were collected for a period of 16 months, from April 1990 to July 1991. One hundred and thirty two plankton samples, each of 20-40 litres of water, were taken using a water sample, at the surface on the ebbing tide on the larvae sampling station (max depth $3 \mathrm{~m}$ ) (Fig. 1). All bivalve larvae 
densities were converted to an equivalent volume (one cubic meter). Plankton samples were replicated and filtered through $63-\mu \mathrm{m}$-mesh gauze immediately after collection. The collected material was fixed with $90 \%$ alcohol. Bivalve larvae were subsequently treated with 5\% sodium hypochlorite solution to digest organic matter. During periods of peak abundance, plankton samples were divided using a Stempel pipette (UNESCO, 1968). Bivalve shells were counted and identified using a Zeiss IM35 inverted microscope. Individual larvae were measured in length (anterior-posterior axis), height (dorso-ventral axis) and hinge area at 100 or $400-X$ using an ocular micrometer. Where possible, larvae were identified to the genus or species level using the keys of Chícharo (1996) and Le Pennec (1978).

\section{Data analysis}

The total abundance of bivalve larvae was expressed in number $/ \mathrm{m}^{3}$. The relationship between parameters was analysed by Pearson's correlation. To avoid assuming a significant correlation due to random processes, the Bonferroni inequalities (Snedecor and Cochran, 1989) were used in the analysis. The value of $t_{0.05}$ was corrected to $t_{0.05 / n^{\prime}}$ (where $n$ ' is the number of pairs of correlations in the matrix). Only after applying this correction did we verify if a correlation was significant.

\section{RESULTS}

\section{Environmental factors}

Water temperature ranged between $13.1^{\circ} \mathrm{C}$ and $27.5^{\circ} \mathrm{C}$, in January 1991 and July 1990 , respectively (Fig. 2A). Salinity values normally varied close to that of normal sea salinity. The lowest value occurred during the winter months (32 PSU in February and March 1991), and a maximum of 38.4 PSU was observed in July 1991 (Fig. 2B). Wind velocity ranged between 0 and $9.7 \mathrm{~m} / \mathrm{s}$. Higher values of wind velocity were registered in December 1990 and May 1991, but no clear seasonal pattern was observed (Fig. 2C). The highest value of chlorophyll a was observed during summer (July; $13.23 \mu \mathrm{g} / \mathrm{l}$ ) and lowest during winter (December; 0.4 $\mu \mathrm{g} / \mathrm{l}$ ) (Fig. 2D). During the spawning season, the tidal amplitude (High tide-Low tide), between May 4 and August 31 1990, was registered and the spring tides occurred May 2325, June 23-25, July 23-26 and August 22-24 (Fig. 3).
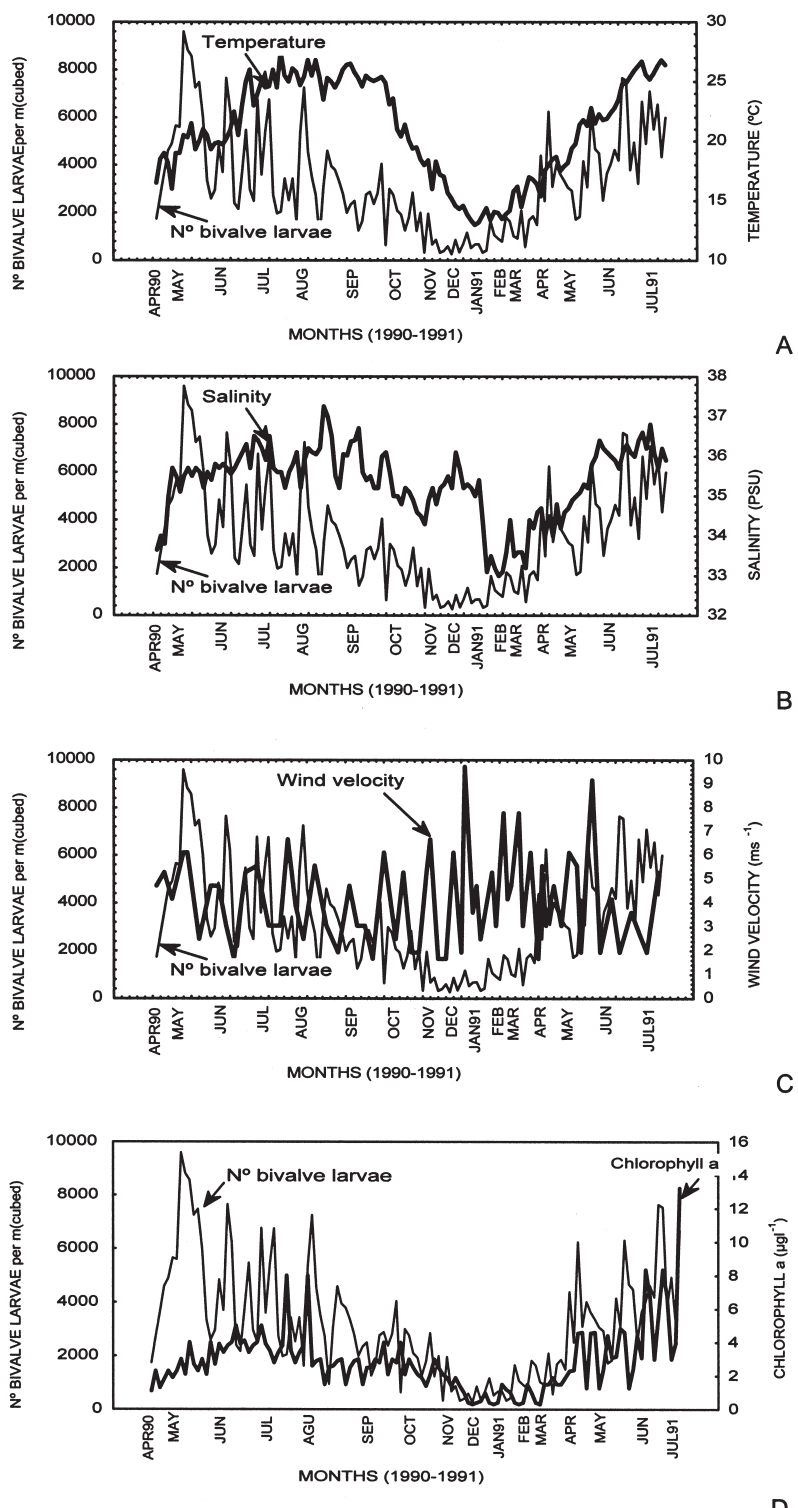

FIG. 2. - Larval abundance and environmental parameters, during the sampling period: A. water temperature, B. Salinity C. Wind velocity D. Chlorophyll a

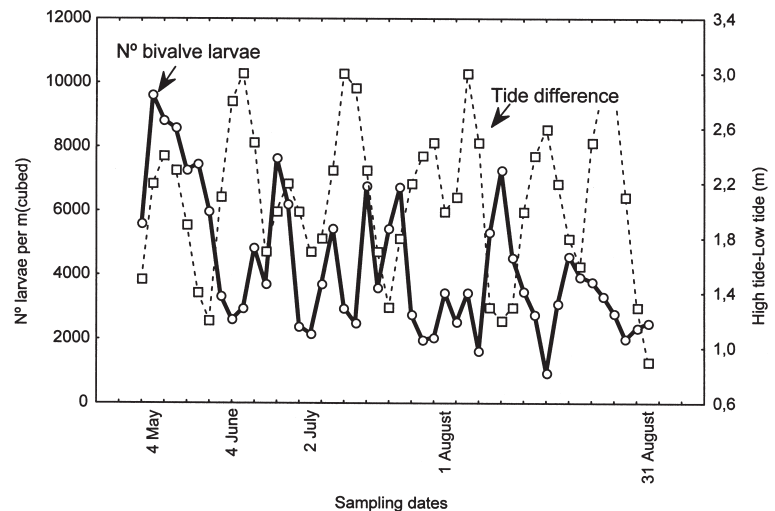

FIG. 3. - Larval abundance and tidal amplitude during the major spawning period of bivalves in the Ria Formosa (Spring tides occurred May 23-25, June 23-25, July 23-26 and August 22-24) 


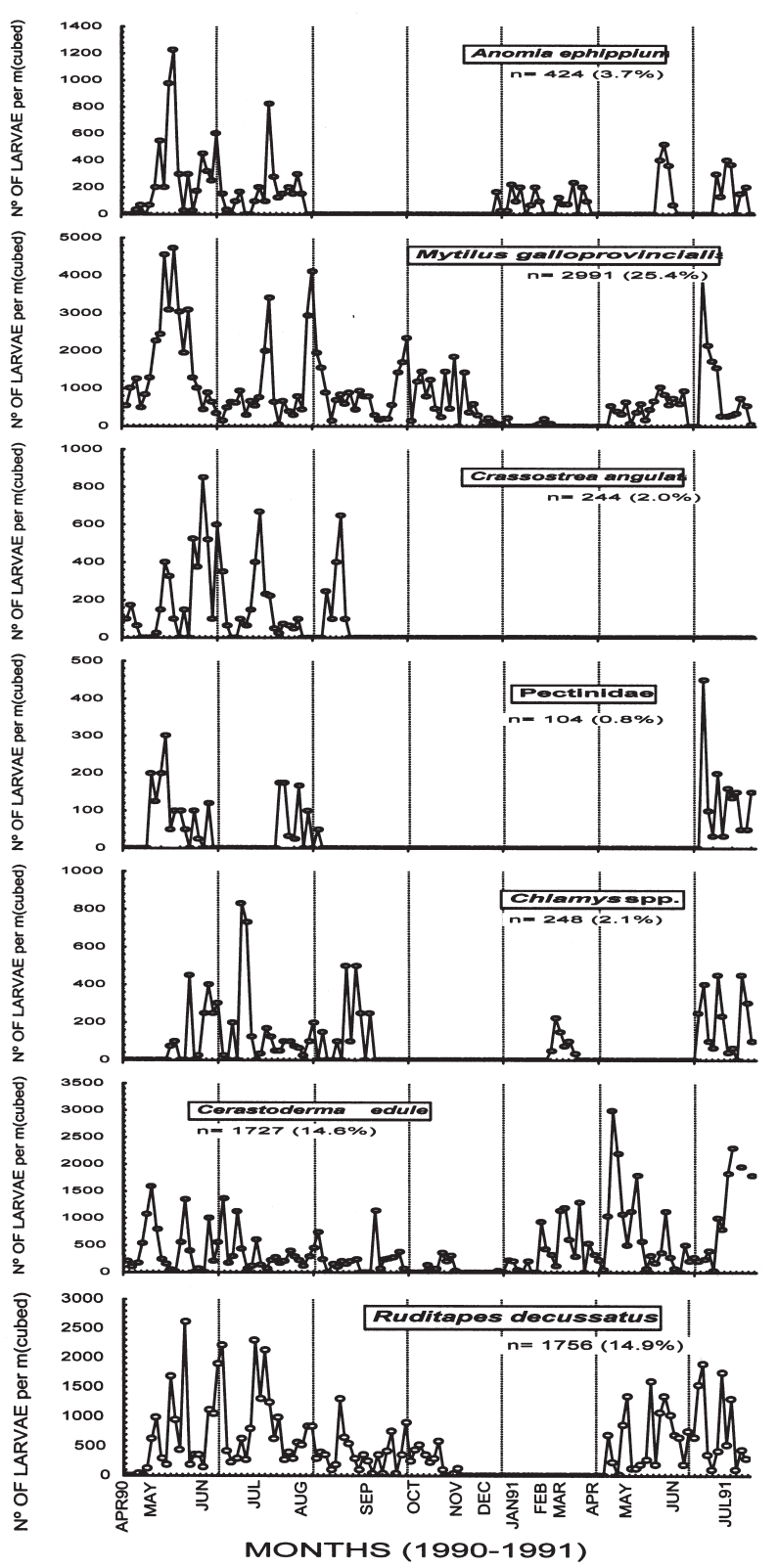

FIG. 4. - Abundance of various bivalve larvae taxa in the plankton of Ria Formosa during the years of 1990 and 1991; $n$ indicates the total number of larvae, and the percentage between parenthesis indicates the relative abundance of each taxa caught.

\section{Taxonomic composition, abundance and temporal distribution}

Eighteen bivalve larval taxa were identified belonging to the superfamilies Mactracea, Tellinacea, Solenacea and Pholadacea; to the family Pectinidae; to the genus Nucula spp., Modiolus spp., Chlamys spp., Acanthocardia spp., Venus spp., Venerupis spp., Chamelea spp. and Hiatella sp.; and to the species Anomia ephippium, Mytilus galloprovincialis, Cerastoderma edule, Ruditapes decussatus and Crassostrea angulata

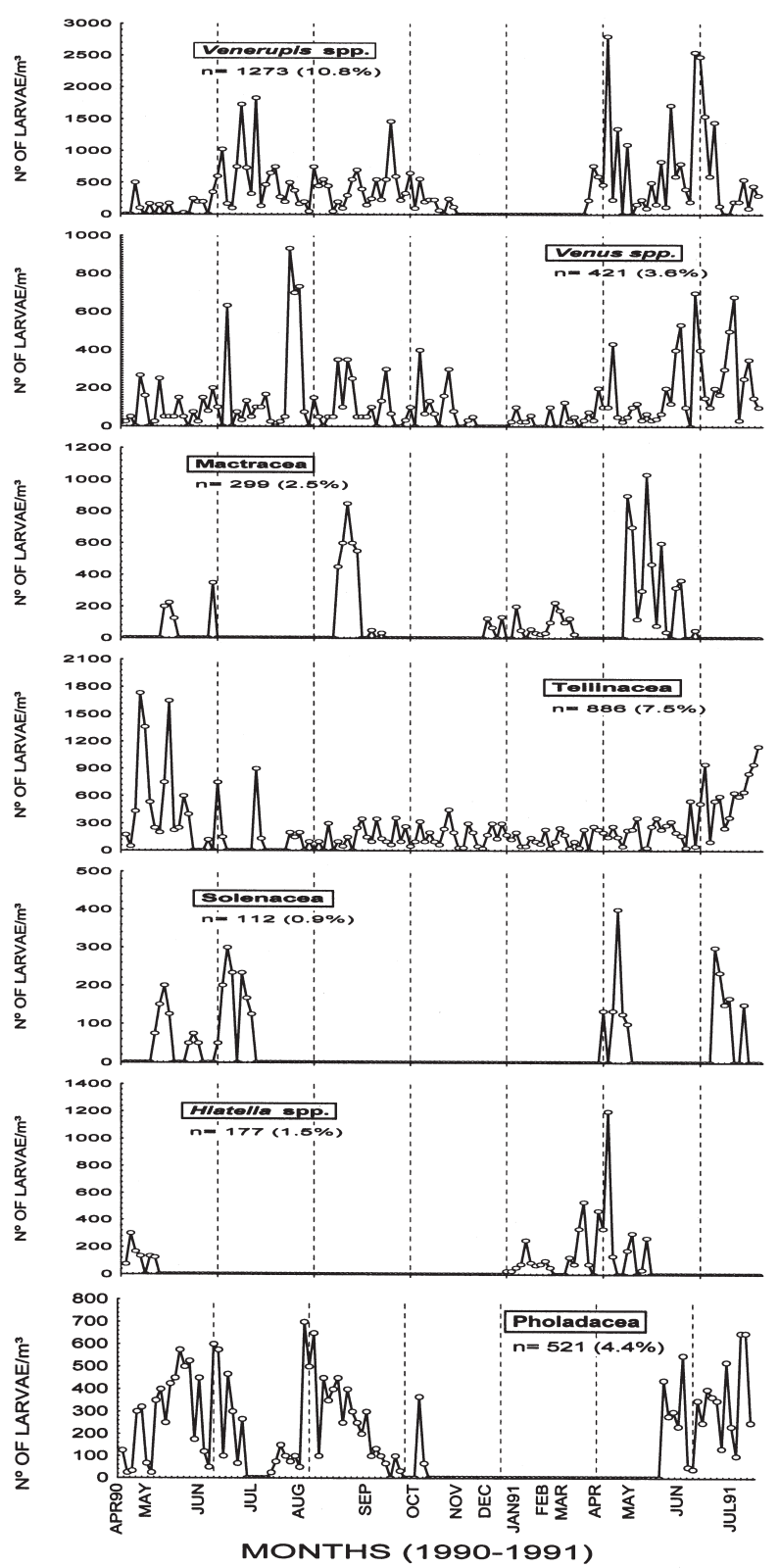

FIG. 5. - Abundance of various bivalve larvae taxa in the plankton of Ria Formosa during the years of 1990 and 1991; $n$ indicates the total number of larvae, and the percentage between parenthesis indicates the relative abundance of each taxa caught.

The most abundant bivalve larvae were those of Mytilus galloprovincialis (25.4\%), Ruditapes decussatus (14.9\%), Cerastoderma edule (14.6\%) and Venerupis spp. (10.8\%) (Figs. 4 and 5). The family Veneridae was the most abundant consisting of $29.39 \%$ of the total bivalve larvae identified, while the family Mytilidae represented $25.59 \%$, the family Cardiidae represented $14.8 \%$ and the superfamily Tellinacea, 7.5\%. Acanthocardia spp. (0.2\%), Modiolus spp., (0.19\%), Chamelea spp. (0.09\%) and Nucula spp. $(0.03 \%)$ larvae were the less abundant and occurred only punctually in the plankton (Figs. 4 and 5). 
Planktonic bivalve larvae were present throughout the entire sampling period (Fig. 2). Bivalve larval abundance began to increase in April 1990 and 1991, and the highest abundance occurred in the beginning of May of 1990. Counts of greater than 1,000 larvae $/ \mathrm{m}^{3}$ were frequent, except during the winter months (November-January). A small increase in abundance was noted from January until April 1991. However, an important variation in the abundance was observed between successive samples.

The analysis of the temporal distribution of the more abundant species showed that Mytilus galloprovincialis larvae were caught almost in all the months, but the maximal value of 4721 individuals $/ \mathrm{m}^{3}$ in May was counted. The abundance of larvae Ruditapes decussatus was high during spring and summer months (Fig. 4). Its maximum larval abundance $\left(3,564\right.$ larvae $\left./ \mathrm{m}^{2}\right)$ was observed in June 1990 , and the minimum larvae abundance (0 lar$\mathrm{vae} / \mathrm{m}^{2}$ ) was caught between November 1990 and March 1991.

The larval abundance of Cerastoderma edule was highest $\left(3,942\right.$ larvae $\left./ \mathrm{m}^{2}\right)$ in April and they were absent between December and November 1990 (Fig. 4).

\section{Relationship between bivalve larval abundance and environmental parameters}

The general correlation of bivalve larval abundance and environmental parameters revealed significant correlations with temperature $(r=0.47$, $\mathrm{p}=0.001)$, chlorophyll a $(\mathrm{r}=0.57, \mathrm{p}=0.001)$, salinity $(\mathrm{r}=0.45, \mathrm{p}=0.001)$ and tide amplitude $(\mathrm{r}=-0.31$, $\mathrm{p}=0.034$ ). The species with abundance equal or higher than $15 \%$ were also included in this analysis: Mytilus galloprovincialis, Ruditapes decussatus and Cerastoderma edule (Table 1).

\section{DISCUSSION}

Bivalve larvae occurred throughout the year in the plankton of the study area. This seems to be common in coastal lagoons. Alcaraz and Domínguez (1985) also observed this in the Ria of Pontevedra (Spain) as did Morgado (1993) in the Ria de Aveiro (Portugal), and Sprung (1994b) in the Ria Formosa. Lebour (1938) noted the continuous presence of bivalve larvae in the plankton throughout the year in Plymouth (U.K.), as did Rees (1954) in the North Sea and Hrs-Brenko (1971) in the Adriatic Sea.

The taxonomic composition of bivalve larvae agreed with the abundance of adult bivalves in the area. In fact, Cerastoderma edule and Ruditapes decussatus are the most abundant bivalves in the lagoon (Calvário, 1995). However, Mytilus galloprovincialis adults are scarce in the Ria and yet the larvae were the most abundant in the plankton and were always present in the samples. Alcaraz and Domínguez (1985), Leal (1989) and Cáceres-Martinez and Figueras (1998b) have also noted their presence almost continuously throughout the year in similar Iberian ecosystems. The rarities of adults in the lagoon are probably because of the few hard substrata available in the Ria Formosa (Chícharo and Chícharo, 2000).

Variation in the total abundance of bivalve larvae showed a clear seasonal pattern, with highest abundance in the spring and summer months and minima in autumn and winter. This was clearly related to the seasonal fluctuation of water temperature. A similar trend between larval abundance and salinity could also be observed. However, temperature seems to be the more important factor in the timing of the reproduction of bivalves (Guillou et al., 1992) and therefore in the fluctuations of the abundance and occurrence of planktonic bivalve larvae.

TABLE 1. - Spearman correlations among the studied environmental parameters $(\mathrm{n}=23, \mathrm{CHLOR}=$ Chlorophyll a $(\mu \mathrm{g} / \mathrm{l}), \mathrm{TEMP}=$ temperature $\left({ }^{\circ} \mathrm{C}\right)$, SALIN=salinity $(\mathrm{PSU})$, WIND=wind velocity $(\mathrm{m} / \mathrm{s})$, TIDE$=$ Tidal amplitude $(\mathrm{m})$, LARVAE $=$ total larvae $\left(\right.$ number $\left./ \mathrm{m}^{3}\right)$, Mytilus, Ruditapes, Cerastoderma $=$ number of larvae $/ \mathrm{m}^{3}, *=\mathrm{p}<0.05$ with Bonferroni correction)

\begin{tabular}{|c|c|c|c|c|c|c|c|c|c|}
\hline & CHLOR & TEMP & SALIN & WIND & TIDE & LARVAE & Mytilus & Ruditapes & Cerastoderma \\
\hline CHLOR & 1.00 & & & & & & & & \\
\hline TEMP & $0.63 *$ & 1.00 & & & & & & & \\
\hline SALIN & $0.5^{*}$ & $0.72 *$ & 1.00 & & & & & & \\
\hline WIND & -0.23 & $-0.18^{*}$ & -0.11 & 1.00 & & & & & \\
\hline TIDE & 0.12 & 0.07 & -0.11 & 0.26 & 1.00 & & & & \\
\hline LARVAE & $0.57 *$ & $0.47 *$ & $0.45^{*}$ & -0.08 & $-0.31 *$ & 1.00 & & & \\
\hline Mytilus & $0.27 *$ & $0.44 *$ & $0.37 *$ & 0.01 & -0.22 & $0.40 *$ & 1.00 & & \\
\hline Ruditapes & $0.62 *$ & $0.61 *$ & $0.54 *$ & -0.23 & $-0.29 *$ & $0.59 *$ & $0.49 *$ & 1.00 & \\
\hline Cerastoderma & $0.25^{*}$ & 0.17 & -0.01 & -0.01 & -0.18 & $0.38 *$ & -0.05 & $0.2 *$ & 1.00 \\
\hline
\end{tabular}


High values of $R$. decussatus larvae in the plankton, usually between May and September, agree with the spawning periods of $R$. decussatus (Vilela, 1947; Banha, 1984). According to these authors, spawning seems to occur when the water temperature rises above $20^{\circ} \mathrm{C}$ and, in general, this was confirmed in the present study. The correlation coefficient indicates that temperature explained a significant component of variation in the abundance larvae of this species.

In contrast to the situation for $R$. decussatus larvae, $C$. edule larvae were present during almost all the year in the plankton of the lagoon. However, intense short-term fluctuations occurred, as has also been observed by Alcaraz and Domínguez (1985). Abundance was higher in 1991 and maximum values occurred in spring. This is in accord with the spawning periods of C. edule (Vilela, 1947; Santos et al., 1986; Guillou et al., 1992). The relationship of this species with environmental parameters revealed that temperature was not related significantly with the abundance of larvae. This can be due to the fact that $C$. edule adults need water temperatures greater than $15^{\circ} \mathrm{C}$ to spawn (Le Pennec, 1978), and water temperatures in the Ria Formosa lagoon were above this limit for almost all the year.

Besides water temperature, chlorophyll a levels also seem to have had some relationship with bivalve larvae. In fact, the quantity and quality of food seem to determine the bivalve larval abundance (Calabrese and Davis, 1970). Nevertheless, according to Sprung (1994b) the net contribution of planktonic forms to primary production in the Ria Formosa is low (only about $45 \mathrm{~g} \mathrm{C} \mathrm{m}^{-2} \mathrm{y}^{-1}$ ) and is mainly restricted to the summer months. The major primary production probably arises from green algal mats that cover mud flats during winter, in the form of inter-tidal and sub-tidal Zoostera beds and in salt marshes surrounding the tidal flats. However, the suspended detritus resulting from these sources could have dimensions unsuitable for filtration by small organisms such as bivalve larvae. The high contribution of phytoplankton to primary production in summer also coincides with the major abundance of bivalve larvae. Moreover, the phytoplankton biomass of the lagoon in late spring and summer is usually dominated by small flagellates (von Brockel, personal communication), which is an appropriate food source for bivalve larvae. In fact all the species analysed displayed significant correlations with levels of chlorophyll a.

Wind velocity, seemed to have little influence on the total bivalve larval abundance. However, there are some reports giving different results. According to Pearce et al. (1998) and Verdier-Bonnet et al. (1997), high water turbulence negatively affects bivalve larvae. This can be related to the fact that low wind velocity was registered during the more intense period of spawning of this species in the present study $(<7 \mathrm{~m} / \mathrm{s})$.

Besides monthly and seasonal fluctuations of bivalve larvae, great oscillations of larvae were registered, with small periods when an absence was registered, alternating with other periods of high abundance. These oscillations seem to be frequent in bivalve larvae. Le Pennec (1978) and Sprung (1994b) have also noted this variation. This could result from the patchy distribution of zooplankton (Hunter, 1981). Nevertheless, the decline of larvae in the plankton can be also related to the settlement of young bivalves (Cáceres-Martínez and Figueras, 1998a, b). However, we believe that the offshore transport by tidal currents is determining this important variation in the larval abundance between successive samples, especially registered during the spawning period. During spring tides, when the renovation of water of the lagoon is almost total, a great reduction of abundance was observed. In fact, tidal amplitude was related negatively with the abundance of larvae. The existence of two bars allowing changes of water masses may result in important losses of larvae to the adjacent ocean. However the existence of some synchronised mechanism of spawning with neap tides may also have developed in some bivalves species, similar to the one described for crustacean and fish (Sinclair, 1988), to avoid the loss of the larvae to unfavourable habitats.

It can be concluded, despite the known limitation of correlation analysis with several environmental factors, that the seasonal fluctuations of bivalve abundance seem to be controlled by temperature, the major factor in the timing of the reproduction of bivalves. However, the short-term fluctuations are related to tidal amplitude (advection). Identifying cause-effect relationships of abundance with some environmental parameters would be a predictive tool for aquaculture and/or natural beds management. Further effort must be applied to obtain longer data series on short-term fluctuations of larval abundance and newly post-larval abundance and of environmental parameters. Moreover, accurate field estimations of mortality rates during planktonic larval life and benthic post-larval life are also necessary for the bivalve species in this coastal lagoon. 


\section{ACKNOWLEDGEMENTS}

The authors are indebted to Prof. Martin Sprung for his criticism and to the team of the German-Portuguese research project 'Die Biologie der Ria Formosa' for the phytoplankton information. We are also grateful Dr. John Nascimento and Prof. Karim Erzini for improving the English.

\section{REFERENCES}

Águas, M. - 1986. Simulação da circulação hidrodinâmica na Ria Formosa. (Hydrodynamic circulation of Ria Formosa). In: M. Gomes Guerreiro, (ed.), Proceedings of "Os Sistemas Lagunares do Algarve”, pp. 78-90. Universidade do Algarve, Faro, Portugal.

Alcaraz, M. and M. Domínguez. - 1985. Larvas de moluscos lamelibranquios en la ria de Pontevedra (NO) de Espana: ciclo anual. Invest. Pesq., 49(2): 165-173.

Banha, L., 1984. Aspectos da biologia (crescimento e reprodução) de Ruditapes decussatus na Ria Formosa - Algarve. Unpublished Graduation Thesis. Universidade de Lisboa, $119 \mathrm{p}$.

Beukema, J.J. - 1991. The abundance of shore crabs (Carcinus maenas) on a tidal flat in the Wadden Sea after cold and mild winters. J. Exper. Mar. Biol. Ecol., 153: 97-113.

Beukema, J.J. - 1992. The abundance of juvenile shrimps (Crangon crangon) on a tidal flat in the Wadden Sea after cold and mild winters. Mar. Ecol. Prog. Ser., 83: 157-165.

Bohle, B. - 1971. Settlement of mussel larvae Mytilus edulis on suspended collectors in Norwegian waters In: Crisp, D.J. (ed.) 4th European Marine Biology Symposium, pp 63-69, Cambridge University Press.

Borsa, P. and B. Millet. - 1992. Recruitment of the clam Ruditapes decussatus in the Lagoon of Thau Mediterranean. Estuar. Coast. Shelf Sci., 35: 289-300.

Cáceres-Martínez, J. and A. Figueras. -1998a. Mussel (Mytilus galloprovincialis Lmk) colonisation on artificial substrates in the Ria de Vigo (NW Spain). J. Shellfish Res., 17: 153-157.

Cáceres-Martínez, J. and A. Figueras. - 1998b. Distribution and abundance of mussel (Mytilus galloprovincialis Lmk) larvae and post-larvae in the Ria de Vigo (NW Spain). J. Exper. Mar. Biol. Ecol., 229(2): 277-287

Calabrese, A and H.C. Davis. - 1970. Tolerances and requirements of embryos and larvae of bivalve molluscs. Helgol. Wiss Meeresunter, 20: 553-564.

Calvario, J. - 1995. Estrutura e dinâmica das comunidades macrobentónicas. Unpublished $\mathrm{PhD}$ Thesis. Universidade do Algarve, $337 \mathrm{p}$.

Camacho, AP. and G. Román. - 1986. La reproduction en los moluscos bivalvos. Bol. Inst. Esp. Oceanogr., 23: 89-93.

Ceccherelli, V.H. and R. Rossi. - 1984. Settlement growth and production of the mussel Mytilus galloprovincialis. Mar. Ecol. Prog. Ser. 16: 173-184.

Chia, F.-S. - 1989. Differential larval settlement of benthic marine invertebrates In: J.S., Tyler, P.A. Ryland (eds.), Reproduction genetics and distribution of marine organisms; 23rd European Marine Biology Symposium pp 3-12. Fredensborg Olsen and Olsen.

Chícharo, L.M.Z. - 1993. Ocorrência de larvas e pós-larvas de bivalves na Ria Formosa. Boletin UCA Universidade Algarve, UCTRA, 1: 479-489.

Chícharo, L.M.Z. - 1996. Sistemática ecologia e dinâmica de larvas e pós-larvas de bivalves na Ria Formosa. Unpublished Ph. D. thesis Universidade do Algarve Faro, $450 \mathrm{p}$.

Chícharo, L.M.Z. and M.A.Chícharo. - 1995. The RNA/DNA ratio as a useful indicator of the nutritional condition in juveniles of Ruditapes decussatus. Sci. Mar., 59(Supl 1): 95-101.

Chícharo, L.M.Z. and M.A. Chícharo. - 2000. Estimation of life history parameters of Mytilus galloprovincialis (Lamarck) larvae in a coastal lagoon (Ria Formosa - South Portugal). $J$. Exper. Mar. Biol. Ecol., 243: 81-94.
Creek, G.A. - 1960. The development of the lamellibranch Cerastoderma edule L. In: Proc. Zool. Soc. London, 135: 243-260.

De Blok J.W. and H.J.F.M. Geelen. - 1958. The substratum required for the setting of mussels (Mytilus edulis L). Archv. Neerland de Zool., 13: 446-460.

Falcão, M., J. Pissarra and M. Cavaco. - 1985. Características físicas e químicas da Ria de Faro- Olhão: 1984 Relatorio INIP 61: $1-24$.

Gaines, S.D. and J. Roughgarden. - 1985. Larval settlement rate: a leading determinant of structure in an ecological community of the marine intertidal zone. Proc. Natl Acad. Sci., USA, 82: 3707-3711.

Gallagher, E.D., P.A Jumars and D.D. Trueblood. - 1983. Facilitation of soft-bottom benthic succession by tube builders. Ecology, 64(5): 1200-1216.

Grassle, J.F. and J. P. Grassle. - 1974. Opportunistic life histories and genetic systems in a marine benthic polychaetes. J. Mar. Res., 32: 253-284.

Grassle, J.P., P.V.R. Snelgrove and C.A. Butman. - 1992. Larval habitat choice in still water and flume flows by the opportunistic bivalve Mulinia lateralis. Netherl. J. Sea Res., 30: 33-44.

Guillou, J., G. Bachelet and M. Glémarec. - 1992. Influence des fluctuations de température sur la reproduction et le recruitment de la coque Cerastoderma edule. Ann. Inst. Océanogr., 68(1-2): 65-74.

Hadfield, M.G. - 1984. Settlement requirements of molluscan larvae: new data on chemical and genetical roles. Aquaculture, 39 : 283-298.

Hines, A.H. - 1986. Larval problems and perspectives in life histories of marine invertebrates. Bull. Mar. Sci. 39: 506-525.

Hrs-Brenko, M. - 1971. Observations on the occurrence of planktonic larvae of several bivalves in the northern Adriatic Sea. In: D.S. McLusky and A T. Berry (eds.), Proccedings of the 4th European Marine Biology Symposium, pp. 45-53, Cambridge.

Hunter, J.R. - 1981. Feeding ecology and predation of marine fish larvae. In: R. Lasker, (ed.), Marine Fish Larvae: morphology, ecology and relation to fisheries, pp. 34-40 Washington Sea Grant (2ed).

Kalyanasundaram, M. - 1987. Ecology and development of some estuarine bivalve larvae. $\mathrm{PhD}$ Thesis. Centre of Advanced Study in Marine Biology. Annamalai University India, 130 p.

Leal, A. M. - 1989. Raft culture of mussels Mytilus edulis L. in Portugal. In: De Pauw N, et al. (eds.), Aquaculture: a Biotechnology in Progress, pp 351-357. European Aquaculture Society, Bredene, Belgium.

Le Pennec, M. - 1978. Génese de la coquille larvaire et post- larvaire chez divers bivalves marins Thése d'État. Université de Bretagne Occidentale Laboratoire de Zoologie Université Brest, 229 pp.

Lebour, M.V. - 1938. Notes on the breeding of some lamellibranchs from Plymouth and their larvae. J. Mar. Biol. Ass. UK, 23: 119144.

Lorenzen, C.J. and S.W. Jeffrey. - 1980. Determination of chlorophyll in seawater. UNESCO Technical Papers in Marine Science, 35: 3-21.

Mann, R. - 1988. Field studies of bivalve larvae and their recruitment to the benthos: a commentary. J. Shellfish Res., 7(1): 1-10.

Maurer, D., L. Watling and G. Abril. - 1979. The distribution and ecology of common marine and estuarine pelecypods in Delaware Bay area. Nautilus, 88: 38-45.

Minchinton, T.E. and R.E. Scheibling. - 1991. The influence of larval supply and settlement on the population structure of barnacles. Ecology, 72: 1867-1879.

Miron, G., B. Boudreau and E. Bourget. - 1995. Use of larval supply in benthic ecology: testing correlations between larval supply and larval settlement. Mar. Ecol. Prog. Ser., 124: 301-305.

Morgado, F. - 1993. Zooplâncton dos canais a Norte da Ria de Aveiro: ciclo anual de abundância. Boletim UCA Universidade Algarve, UCTRA, 1: 380-399.

Pearce, C.M., Gallager, S.M., Manuel, J.C., Manning, D.A., O'Dor, R.K. and E. Bouget. - 1998. Effect of thermoclines and turbulence on depth of larval settlement and spat recruitment of giant scallop, Placopecten magellanicus, in $9.5 \mathrm{~m}$ deep laboratory mesocosmos. Mar. Ecol. Prog. Ser., 165: 145-215.

Petersen, C.H. - 1982. The importance of predation and intra and interespecific competition in suspension-feeding bivalves, Prothothaca staminea and Chione undatella. Ecol. Monogr., 52, 437-475 
Pihl, L and R. Rosenberg. - 1983. Food selection and consumption of shrimp Crangon crangon in some shallow marine areas in western Sweden. Mar. Ecol. Prog. Ser., 15: 159-168.

Powell, E.N., Cummins, H., Stanton, Jr R.J. and G. Staff. - 1984. Estimation of the size of molluscan larval settlement using the death assemblage. Estuar. Coast. Shelf Sci., 18: 367-384.

Powell, E.N., Stanton Jr, R.J., Davies, D and A. Logan. - 1986. Effect of a large settlement and catastrophic mortality on the ecologic record of the community in the death assemblage. Estuar. Coast. Shelf Sci., 23: 513-525.

Rees, C.B. - 1954. Continuous plankton records: The distribution of lamellibranch larvae in the North Sea, 1950-51. Bull. Mar. Ecol., 4(27): 21-46.

Roegner, G.C. and R. Mann. - 1995. Early recruitment and growth of the American oyster Crassostrea virginica (Bivalvia: Ostreidae) with respect to tidal zonation and season. Mar. Ecol. Prog. Ser., 117: 91-101.

Santos, A.C., Castro, J.J. and L. Raimundo. - 1986. O canal de Tavira - Ria Formosa - Algarve: caracterização geral do meio e análise da estrutura, dinâmica e produção das populações de Cerastoderma edule, Solen marginatus e Spisula solida. Unpublished Graduation thesis. Universidade de Lisboa. Faculdade de Ciências. Departamento de Zoologia e Antropologia. Laboratório Marítimo da Guia, $450 \mathrm{p}$.

Seed, R. - 1969. The ecology of Mytilus edulis L (Lamellibranchiata) on exposed rocky shores I-breeding and settlement. Oecologia, 3: 277-316.

Sinclair, M. - 1988. Marine populations. An essay on population regulation and speciation. Books in Recruitment Fishery Oceanography.Washington Sea Grant

Snedecor, G. and W. Cochran. - 1989. Statistical methods. Iowa State University press, Ames, Iowa
Sprung, M. - 1994a. Macrobenthic secondary production in the intertidal zone of Ria Formosa-a lagoon in southern Portugal. Estuar. Coast. Shelf Sci., 38: 539-558.

Sprung, M. - 1994b. High larval abundances in the Ria Formosa (Southern Portugal) - methodological or local effects? J. Plankton Res., 16(2): 151-160

Strathmann, R.R. - 1985. Feeding and non-feeding larval development and life history evolution in marine invertebrates. Ann. Rev. Ecol. Syst. 16: 339-361.

Sullivan, C.M. - 1948. Bivalve larvae of Malpeque Bay. Bull. Fish. Res. Board Canada, 77: 1-36.

Thorson, G. - 1950. Reproductive and larval ecology of marine bottom invertebrates. Biol. Ver., 25: 1-45.

Thorson, G. - 1966. Some factors influencing the recruitment and establishment of marine benthic communities. Neth. J. Sea Res., 3(2): 267-293.

UNESCO. - 1968. Zooplankton sampling: Microzooplankton. pp 150-152. Report of Working Party, Monographs on oceanographic methodology 1.

Vance, R. R. - 1973a. On reproductive strategies in marine benthic invertebrates. Am. Nat. 107 (955): 339-352.

Vance, R.R. - 1973b. More on reproductive strategies in marine benthic invertebrates. Am. Nat. 107 (955): 353-361.

Verdier-Bonnet, C., Carlotti, F., Rey C. and M. Bhaud. - 1997. A model of larval dispersion coupling wind-driven currents and vertical larval behaviour: application to the recruitment of the annelid Owenia fusiformis in Banyuls bay, France. Mar. Ecol. Prog. Ser. 165: 217-231.

Vilela, H. - 1947. Contribuição para o estudo das comunidades animais dos parcéis da Ria de Faro. Arq. Mus. Bocage, 18: 97-164.

Scient. ed.: M. Alcaraz 